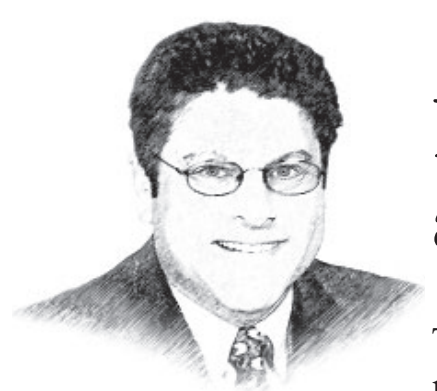

\title{
Recognizing a retirement, and a calcium deposition syndrome
}

This month, I want to devote the bulk of my editorial space to a personal note about changes in our CCJM editorial community. Ray Borazanian, who has been our managing editor for over 2 decades, is retiring as of April 2.

Upon reading (and editing) a retirement biosketch written by others for internal dissemination, Ray quipped in an e-mail that the "Borazanian guy appears to be a fine fellow." That is as strong a self-promotional statement he has likely ever written. Forever the guy behind the curtain, he has quietly and competently translated clinicians' writing into clear, readable, understandable English, in addition to verifying references and numbers and correcting tables. And he has done this with full realization that authors might take umbrage at having their stilted, plodding language "dumbed down" to simple and clearly expressed declarative statements. I recall my own reaction when receiving and reading the final galley proof of the first paper I submitted to CCJM. It was clearly not exactly what I had written-it was much clearer. Other journals I had published in had never edited like that. This CCJM approach to editing was equally driven, embraced, and enacted by other in-house editors Dave Huddleston and Phil Canuto, but I don't think any took the pushback by authors harder and more personally than Ray. This "stylistic" editing, as I defended it to authors, paid off in many ways. These included getting surprise, unsolicited recognition by the Plain Language Action and Information Network (PLAIN), "an unfunded working group of federal employees from different agencies and specialties who support the use of clear written communication." They wrote, "How did the editors of the Cleveland Clinic Journal of Medicine dramatically increase their readership? By replacing their journal's dense, long-winded, jargon-filled style with an alternative style that incorporates the principles of plain language." 1

Ray joined Cleveland Clinic as a research assistant in the Department of Hypertension and Nephrology in 1986. He coauthored several papers relating to hypertension with icons in the field, Ray W. Gifford, Jr., and Donald Vidt. He subsequently expanded his clinical editing activity and joined the CCJM as a manuscript editor. When Dave Huddleston, the Managing Editor at the time, left the Journal to do a stint in the Peace Corps, Ray quite ably assumed that position. Dave has long since returned to CCJM as Editorial Project Leader. With Ray's retirement, Dave will, fortunately for all, now reprise his role as Managing Editor.

We have had other changes within our core editorial group over the past year, several of which I have previously noted in editorial comments. These changes were made more challenging by our pandemic-necessitated physical separation, with our nonphysician editorial team members all working from home. The personality of the Journal is fundamentally unchanged, something that I am personally quite thankful for and that I attribute in large part to the leadership of Peter Studer, our executive publisher. But changes there are, professional and personal.

As readers who are fans of classic British rock and roll may readily appreciate, it has been amusingly special to me to refer to our creative editing team of Ray and Dave. 
Although only those of a certain age will get what I am alluding to, I can't do it any longer with Ray's retirement. I have appreciated that neither of these musically adroit "fine fellows" has over the years red-penned out my editorial musical references.

Thank you, Ray. (And yes, I will try to remember that you do not like the use of parenthetic comments).

There is also clinical content in this issue of the Journal worth highlighting, relating to the biological and clinical impact of soft-tissue calcium deposition. Calcium deposition in articular and periarticular structures is associated with an odd paradox: it is both under- and over-attributed as a cause of specific clinical syndromes. Chondrocalcinosis is commonly seen on radiographs of knees and wrists, particularly in older patients. But its presence is not equivalent to the clinical syndrome of recurrent acute calcium pyrophosphate arthritis (pseudogout). Conversely, inflammatory chronic calcium pyrophosphate arthritis of the metacarpophalangeal joints and wrists, which is most reliably diagnosed by documenting the presence of calcium pyrophosphate crystals within neutrophil-predominant inflammatory synovial fluids, often in the absence of radiographic calcium deposition, can easily be misdiagnosed as seronegative rheumatoid arthritis if synovial fluid is not obtained and analyzed for the presence of crystals.

A unique calcium pyrophosphate crystal-associated inflammatory syndrome of the cervical spine, crowned dens syndrome, is discussed in 2 papers in this issue. ${ }^{2,3}$ This is a syndrome that I believe is underdiagnosed, recognized mainly in its florid presentation as a pseudomeningitis or pseudocervical spine abscess. And yet, as described in 2013 by Chang et al, a group led by Donald L. Resnick at University of California San Diego, in patients over age 60 the prevalence of atlantoaxial calcium pyrophosphate crystal deposition on computed tomography was $34 \%$, jumping to $49 \%$ in patients age 80 and older. ${ }^{4}$ Often not recognized on magnetic resonance imaging, this calcium deposition should be looked for with computed tomography in the appropriate clinical context.

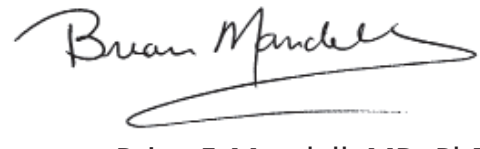

Brian F. Mandell, MD, PhD Editor in Chief

1. Whiteman L. Scientists need plain language. Plain Language Action and Information Network 2000. Accessed March 15, 2021. https://www.plainlanguage.gov/resources/articles/scientists-need-plain-language/

2. Mizumoto J. Crowned dens syndrome: caution about asymptomatic calcification. Cleve Clin J Med 2021; 88(4):204-205. doi:10.3949/ccjm.88a.20184

3. Rosenthal AK. Calcium pyrophosphate deposition and crowned dens syndrome. Cleve Clin J Med 2021; 88(4):206207. doi:10.3949/ccjm.88a21008

4. Chang EY, Lim WY, Wolfson T, et al. Frequency of atlantoaxial calcium pyrophosphate dihydrate deposition at CT. Radiology 2013; 269(2):519-524. doi:10.1148/radiol.13130125 